\title{
Academy of Municipal Engineering in the 1930s: The Failed Scientific Center of Urban Planning
}

\author{
Yulia Kosenkova ${ }^{1, *}$
}

\begin{abstract}
${ }^{1}$ Scientific Research Institute of the Theory and History of Architecture and Urban Planning, Branch of the Central Institute for Research and Design of the Ministry of Construction and Housing and Communal Services of the Russian Federation, Moscow, Russia

*Corresponding author. E-mail: jkosenkova@yandex.ru
\end{abstract}

\begin{abstract}
The article focuses on the creation of the Academy of Municipal Engineering, its structural organization and activities in the 1930s - early 1940s in the field of urban planning of socialist cities. It is shown that during this period the Academy was considered to be of great importance not only as the leading center of scientific urban planning but also as the coordinator of all research work in the country in the field of urban planning, urban sanitation and hygiene as well as landscaping of cities. The article analyzes to what extent the real structure of the Academy's activity and its scientific results corresponded with these expectations. The work of the Academy in the field of urban planning of socialist cities is revealed in the context of the general development of urban planning in the country during this period. It is shown that while the urban planning segregated from the general field of urban development problems and was imbued with specific Soviet, ideologically loaded features, the Academy's activity has been increasingly focusing on technical issues of urban economy, and urban planning problems have occupied less and less space in its work. The collisions of the Academy's scientific work over the basic governmental task - the project of urban planning norms - are shown. The negative impact of political trialson the working conditions of the Academy in the 1930s is also revealed.
\end{abstract}

Keywords: architecture and urban planning of the Soviet period, urban planning of socialist cities, design of residential areas, usage of cultural heritage, urban economy

\section{INTRODUCTION}

The overview of the development of urban planning in the USSR in the 1930s would have been incomplete without studying the activities of the Academy of Municipal Engineering (AME) under the Council of People's Commissars of the RSFSR. It is surprising that it was the Academy of Municipal Engineering that, despite its republican, not the all-union status, was entrusted with a responsibility to become the main scientific center of the country not only in the field of communal services but also in the field of urban planning. From this point of view studying the activity of the AME and its ambiguous role in the architectural and town-planning process of the 1930s is an important task.

*The Reported study was funded by Science and Technology Development State Program of the Russian Federation for years 2013-2020, Program of Fundamental Research of State Academies of Science for years 2013 - 2020, within Program of Fundamental Researches of Ministry of Construction, Housing and Utilities of the Russian Federation and Russian Academy of Architecture and Construction Sciences, the Research Project 1.2.1.

\section{THE INITIAL PERIOD OF WORK OF THE} AME: HIGH HOPES

The Academy of Municipal Engineering was organized in accordance with the decision of the famous June Plenum of the Central Committee of the All-Union Communist Party of Bolsheviks in 1931, dedicated to the development of urban economy in Moscow and other cities of the USSR. At the same time two large centralized management organizations have been created, to which the activity of the AME would be closely connected in the future: the All-Union Council of Municipal Engineering under the Central Executive Committee of the USSR at the Union level, and-The People's Commissariat of Municipal Engineering of the RSFSR at the republican level. The importance of the Academy of Municipal Engineering as a scientific center was reflected in the fact that it was subordinated to the republican People's Commissariat (functionally analogous to a ministry), but directly to the republican government - the CPC of the RSFSR (Council of People's Commissars of the RSFSR). 
It was stated in the initial draft of the structure of the Academy of Municipal Engineering, submitted for the approval of the government, that the AME, in addition to developing a comprehensive set of specific issues of urban economy, should deal with the issues of socialist settlement system, urban planning of new cities and reconstruction of existing settlements [1].

In addition, among its tasks was the training of managerial and higher scientific personnel for the whole sector of urban economy, and the publishing of scientific, educational and popular literature. All this scope of work was supposed to be carried out through eleven scientific institutes organized within Academy, and it was also planned to transfer "all research cells", scattered across research institutions of different departments, to the Academy and its institutes [2].

These plans have not been implemented for organizational, financial and personnel reasons. In its final version, the structure of the Academy became much more compact. Eleven scientific institutes were replaced by eight scientific sectors: socialist urban planning of populated areas; economics of communal services and housing; materials and structures for communal services and housing; power engineering of populated areas; sanitary engineering; road transport; greenspace expansion; residential and communal construction. The first three sectors were considered to be "synthetic", i.e. covering more general, central problems, and of these, the sector of "socialist urban planning of populated areas" was recognized as leading in relation to the rest.

Despite its more modest final structure, the Academy was not spared of the task of becoming the organizing and guiding scientific center covering the activities of all research institutes in all branches of municipal engineering, as well as of creation of the network of local branches (filiations) in major industrial cities. It was believed that the non-departmental nature of the Academy would made it possible to cooperate and coordinate all research work in the field of urban economy and town planning under the guidance of the AME.

A number of measures was taken for this purpose: The Academic Board of the AME was established, as well as the Permanent Council, which met to work out the general plan of research (it included up to 33 organizations of different departmental affiliation). "Assistance councils" were planned, with the participation of executive officials of state and mass organizations, and a number of special bureaus, which should have connected in different ways with the periphery of the country. The scope of the forthcoming work was also confirmed by plans to create an extensive support department consisting of librarians, bibliographers, referees, translators, editors, etc. These plans were only partially implemented [3].
Such a structure of the AME was considered only as an initial scheme. Later on, it was supposed to create branches in different cities and to develop scientific sectors of the AME into a system of central institutes headed by the Institute of Socialist Urban Planning. However, the circumstances were such that these plans were not destined to come true.

\section{PRINCIPLES OF WORK AND MAIN TOPICS IN THE FIELD OF URBAN DEVELOPMENT}

The principles upon which the work of the sector of "Socialist Urban Planning of Populated Areas" were based, have been described in detail in the first issue of AME's collection of scientific works. The main idea was "to bring the scientific base to the construction of cities in the shortest possible time". [4]. Such a strange formulation was not accidental. When in 1928 the first five-year plan was approved, the construction of "socialist cities" near newly emerging industrial plants has not been regulated at the state level. Their design and construction were largely spontaneous; urban planning science did not keep in pace with the rapidly developing practice.

The main methods of creating said scientific base should have been, firstly, the analysis and evaluation of all the existing practices of urban construction; secondly, the developing of theoretical points - of what, in fact, a socialist city should be. There were some paradoxical features here. It was believed that attention should be paid mainly to the analysis of Soviet practice, although it was acknowledged to be imperfect. The basis for the urban planning theory was supposed to be found, firstly, in the works of the founders of Marxism, and secondly, in party and government regulations which were, in fact, just operational documents. The AME planning sector worked in line with these trends.

Thus, for example, the Academy carried out a survey of construction practices of the large new cities, which were parts of the Uralo-Kuznetsky plant - a giant coal-metallurgical enterprise, which has been created in these years in the USSR, as well as a survey of the reconstruction practices of the cities of "Big Volga". The generalization of practice was also at the core of "Residential Area of a New Socialist City" survey, which has been developed by a team led by engineer S.M. Gorny [5]. The team of architect N. A. Ladovsky worked on generalizing the practice of design and reconstruction of residential areas of existing cities, with the plan to implement the results of the research for the experimental design of Moscow districts [6].

The government carried grand plans for the future economic development of the Central Asian region, the construction of new cities there and the radical transformation of old "feudal" cities. Therefore, two 
other directions of the research have been developed within the program of "Socialist Urban Planning in The National Regions of the USSR". One of them, "Socialist Reconstruction of Central Asian Cities", was carried out by a special brigade under the direction of architect V. Popov, who took part in the planning of cities in the Fergana Valley of Uzbekistan [7]. Another topical direction at that time was "Fundamentals of Socialist Settlement of Nomads Exemplified by Kyrgyzstan", which was developed on the basis of research conducted by a joint comprehensive expedition of the Academy of Sciences of the USSR and the AME to Kyrgyzstan in 1932-1933 [8]. The member of the expedition, architect V. Kalmykov, developed a series of designs of houses and blocks for settling nomads on the basis of the national traditional dwellings; this project is well known in the historiography of Soviet architecture. On this basis he created a scheme for reconstruction of the capital of Kyrgyzstan- the city of Frunze [9]. These projects have not been implemented.

A much more realistic line of work was led by one of the most experienced planners, engineer M.I. Nazaretov: the planning of Khalilovo city for 150 thousand residents in the Orsko-Khalilovsky industrial district. This topic was considered to be a complex one, so it included the work of all scientific sectors of the AME [10]. Design deadlines were extremely tight. Despite that, the project managed to cover all aspects of planning and construction of the city, up to the schedules of work and locations of factories for producing construction materials [11]. However, this complex scientific experimental project was also not implemented: the government moved the construction of the metallurgical plant to a new site and the design of the Novo-Orsk -the only city of the entire area- was entrusted to another organization.

In the planning sector of the AME special attention was paid to the direction of "Architectural Organization of Socialist Cities". Its novelty and importance were emphasized in every possible way. One of the most significant topics was the study of the Renaissance urban planning heritage in order to identify the patterns of the composition of architectural ensembles for the purposes of using it in the design of socialist cities. The authors, architects A.V. Bunin and M.G.Kruglova, considered the analysis of the heritage to be the first part of their work, while the second part was to develop ways to applicate the revealed architectural methods to the design of new cities. The latter was never carried out, and the research, having started as a practical one, grew into a purely academic historical-architectural survey, which turned out to be in great demand by the architectural community [12]. In the preface to their book, the authors of the study of old residential quarters of Moscow have also referred to practical goals as constraining limits [13].
The Academy of Municipal Engineering found it quite difficult to compete with other scientific institutions in the field of urban theory. For example, in 1933, the planning sector of the AME completed the work in which the party and government directives on the planning and reconstruction of socialist cities were collected and summarized. But at the same time, the Institute of Economics of the Communist Academy (the all-Union scientific institution engaged in the study of the issues of socialist construction on the basis of the ideas of Marxism-Leninism) developed a comprehensive program that included the analysis of the works of the founders of Marxism-Leninism, the analysis of the practice of developing a large number of new cities and of the problems of socialist reconstruction of old cities [14]. The Communist Academy also published the Marxist-Leninist textbook on urban developing, which was positively assessed by the critics of that time [15].

It was impossible for the AME to cope with the parallel implementation of many scientific topics in other institutions. Thus, the work on town-planning standards, which remained the main governmental task for the Academy during the 1930s, was duplicated at the all-Union level, in the section of urban planning and socialist reconstruction of the cities of the All-Union Council of Municipal Engineering, which had more opportunities to involve large scientific and design organizations in cooperation. At the same time the development of town-planning standards continued in design organizations, scientific institutes of the sanitary-hygienic profile, etc.

The Academy of Municipal Engineering, although not directly subordinated to the All-Union Council of Municipal Engineering (ACME), periodically had to report to this organization. At the same time, ACME actively promoted its own project of town-planning standards and criticized the project of AME. If there were proposals to raise the status of the AME and turn it into an all-Union Academy in the early 1933[16], in 1936, at the first all-Union meeting on urban planning, convened by the ACME in January, the Academy was harshly criticized not only for its project of urban planning standards, but also for the lack of a sufficient number of published theoretical and practical works on urban planning [17]. In March 1936, the status of the AME was lowered-it ceased to be directly subordinate to the government and was transferred under the supervision of the People's Commissariat of Municipal Engineering of the RSFSR.

Publishing difficulties of the AME most likely occurred due to the lack of funding. Thus, the most important scientific topics, including those related to urban planning, were supposed to be covered in detail in the collections of "Scientific Works of the Academy of Municipal Engineering", but only two periodical 
issue shave been published plus one special thematic issue. Many publications announced in the newsletters of the AME have been postponed year by year, and some extensive works of major scientists have been published "on the rights of the manuscript", i.e. multiplied with the use of primitive techniques. The problems of premises, laboratories and equipment were not solved either. The construction of a six-storied building for the AME designed by the famous architect I. A. Golosov started in 1933, but due to the criticism of the Academy, it was not possible for the AME to move in.

In 1936-1937 it was acknowledged that the AME was not able to lead and coordinate scientific research work on housing and communal services in the USSR. It was necessary to create a completely new agency for this purpose. In its turn, the ACME was also criticized soon. It was blamed for the unfortunate situation with the town development and was liquidated in August 1937. ACME's project of town-planning norms was not published, nor was AME's.

\section{CRITICISM OF THE ACADEMY IN THE SECOND HALF OF THE 1930S}

The situation in the country's municipal engineering in the second half of the 1930s was directly related to political trials, in particular, the process of the "Parallel Anti-Soviet Trotskyist Center" in January 1937, which involved prominent Soviet figures. The following February-March plenum of the Central Committee of the All-Union Communist Party of Bolsheviks in 1937 was of special importance not only for the history of "Great Terror", but in particular, for the municipal engineering of the country. Almost all the reports and speeches at this plenary session boiled down to that the country was flooded with "spies, saboteurs and wreckers" who had reached the highest positions.

Immediately after the plenum, on March 14-16, 1937, a meeting of the executive officials of the People's Commissariat of Municipal Engineering was held, where "enemies of the people" were accused of all the drawbacks in urban development. The report of the second (after F.Y. Svetlov) director of the AME Troshin [18], which was soon also declared the "enemy of the people", was harshly criticized. A.V.Shalev was appointed as the new director of the Academy, but not for long as the criticism of the Academy continued.

The peak of this criticism was at the end of 1937 the beginning of 1938. The resolution of the CPC of the RSFSR dated May 27, 1938, noted that the Academy did not fulfill the tasks set before it by the June plenum of 1931. All the drawbacks in its work were put as its fault - the drawbacks, which the Academy had previously been complaining about itself (late approval of scientific plans, lack of premises, laboratories and necessary equipment, difficulties with the publication of studies, the "flow" of researchers, the collapse in the training of senior management and scientific personnel, etc.). Decreasing the status of the Academy was also attributed to the actions of enemies. Particular indignation was caused by the failure to develop the most relevant project — "Norms and Methods of Urban Planning", although in fact the attempts to develop unifying norms for urban planning of the whole country, so diverse in its conditions and so poorly surveyed, were doomed to fail from the start. Nevertheless, in July 1938, the Academy was again directly subordinated to the CPC of the RSFSR and was promised a laboratory base and the necessary funds. The Academic Board, which had not worked for more than two years, was restored [19]. It was significantly expanded and supplemented by authoritative specialists.

The work on town planning standards was resumed in the planning sector of the AME, now on a wider research base, with the involvement of many outside specialists and organizations. Planning norms have been developed only for the general layouts of the cities; norms for detailed planning of towns, as well as of worker's settlement and centers of agricultural areas only were to be developed in the future [20]. In accordance with the decision of the Committee for Construction under the CPC of the USSR (established in February 1938), the AME's project of town-planning standards was published in the journal "Communal Construction" in 1939, and in 1940 it was published as a separate edition [21]. The draft standards were to be widely discussed by the architectural community and town planners. The Second World War, which radically changed the urban planning situation in the country, stopped further work in this direction.

\section{CONCLUSION}

In the 1930s, Soviet urban development was undergoing major transformations. Architecture as a whole moved away from the principles and practices of the avant-garde, relying more and more on the "acquisition of classics", becoming increasingly pretentious. Similarly, urban planning was less and less connected with the traditions of the "functional city"; the leading idea was now to create a single "ensemblecity", designed to demonstrate the success of the socialist state. The search for artistic means of solving urban planning problems was not in the main field of activity of the Academy of Municipal Engineering, and in the late 1930s, despite the continuation of work on urban planning standards, it actually withdrew from urban planning topics, focusing on economic and technical problems of urban economy. The planning sector played a much smaller role in the structure of the Academy, and in the postwar years was liquidated. 


\section{References}

[1] N. Popov-Sibiryak, Let's Organize the Academy of Municipal Engineering (Organizuem Akademiyu Kommunalnogo Hozyaystva) in Kommunalnoe Delo, 1931, No 8, pp.13-14 [in Russian].

[2] P.M.Tolstoy, The Structure of The Academy of Municipal Engineering (Struktura Akademii Kommunalnogo Hozyaystva) in Trudy Akademii Kommunalnogo Hozyaystva, issue 1. Moscow: Gosstroyizdat, 1933, pp.31-42 [in Russian].

[3] The Department of Scientific and Technological Support (Otdel Nauchno-Vspomogatelnyy) in Trudy Akademii Kommunalnogo Hozyaystva, issue No1. Moscow: Gosstroyizdat, 1933, pp.135138 [in Russian].

[4] The Sector of The Social Planning of Populated Areas (Sektor Socplanirovki Naselennyh Mest) in Trudy Akademii Kommunalnogo Hozyaystva, No 1. Moscow: Gosstroyizdat, 1933, pp.67-81 [in Russian].

[5] S.M. Gornyi, Living Street (Zhilaya Ulica) in Planirovka I Stroitelstvo Gorodov, 1935, No 12, pp.22-25[in Russian].

[6] D. Rosenberg, At the Academy of Municipal Engineering (V Akademii Kommunalnogo Hozyaystva) in $\mathrm{Za}$ Socialisticheskuyu Rekonstrukciyu Gorodov, 1933, No 5, pp.56-57 (back cover) [in Russian]

[7] V. Lavrov and V. Popov, To the Problem of Urban Reconstruction in Central Asia. Article No1 (K Probleme Rekonstrukcii Gorodov V Usloviyah Sredney Azii. Statya Pervaya) in Sovetskaya Arhitektura, 1931, No 3, pp. 30-37 [in Russian].

[8] Proceedings of The Kyrgyz Complex Expedition Of 1932-1933 (Trudy Kirgizskoy Kompleksnoy Ekspedicii 1932-1933). Moscow: ANSSR, 1933 [in Russian].

[9] V.Kalmykov, Architectural and Planning Problems in Central Asia (Arhitekturno-Planirovochnye Problemy Sredney Azii) in Planirovka I Stroitelstvo Gorodov, 1935, No 2, pp. 27-33 [in Russian].

[10] Academy of Municipal Engineering. Newsletter (Akademiia Kommunalnogo Hozyaystva. Informacionnyy Byulleten), 1934, No 4-5 (16-17), p.29 [in Russian].

[11] M.I.Nazarethov, Socialist City Khalilovo (Socgorod Halilovo) in Academy of Municipal Engineering. Sector of Residential and Public Buildings, Collection of Scientific Works (Akademiya Kommunalnogo Hozyaystva. Sektor Zhilyh I Obshchestvennyh Zdaniy, Sbornik Nauchnyh Trudov). Moscow, 1935, pp.56-95[in Russian].

[12] A.V.Bunin and M.G.Kruglova, Architecture of Urban Ensembles. Renaissance. Academy of Municipal Engineering (Arhitektura Gorodskih Ansambley. Renessans. Akademiya Kommunalnogo Hozyaystva), ed. by I.L.Matsa, chief ed. A.G.Gabrichevsky. Moscow: Publishing House of The AllUnion Academy of Architecture, 1935 [in Russian].

[13] P.Goldenberg and B.Goldenberg, The Planning of The Residential Quarter of Moscow in 17th, 18th and 19th Centuries (Planirovka Zhilogo Kvartala Moskvy XVII, XVIII I XIX vv.) Academy of Municipal Engineering. Moscow - Leningrad: ONTI, United Scientific And Technical Publishing House, Main Editorial Board of Construction Literature, 1935 [in Russian]

[14] The Report At the Section of The Socialist Settlement of The Institute of Economics of The Communist Academy (V Sekcii Socialisticheskogo Rasseleniya Instituta Ekonomiki Komakademii) in Za Socialisticheskuyu Rekonstrukciyu Gorodov, 1933, No 4. pp. 51-52 [in Russian].

[15] Communist Academy of The CEC Of The USSR. Institute of Economics. Urban Construction. Marxist-Leninist Reader (Kommunisticheskaya Akademiya Pri CIK SSSR. Institut Ekonomiki. Gorodskoe Stroitelstvo. Marksistsko-Leninskaya Hrestomatiya. Ogiz. Sotsekgiz), 1934 [in Russian].
[16] To A Higher Level of Research Work (Na Bolee Vysokuyu Stupen Nauchno-Issledovatelskuyu Rabotu) in $\mathrm{Za}$ Socialisticheskuyu Rekonstrukciyu Gorodov, 1933, No 1, p.49 [in Russian].

[17] N.D.Efremov, On Research Work on Urban Planning (O Nauchno-Issledovatelskoy Rabote Po Planirovke Gorodov) in Socialisticheskiy Gorod, 1936, No 8, pp.27-30 [in Russian]

[18] Asset Meeting of The Executive Officials of the People's Commissariat of Municipal Engineering of the RSFSR (Sobranie Aktiva Rabotnikov Narkomhoza RSFSR) in Socialisticheskij Gorod, 1937, No 4, pp.25-28 [in Russian].

[19] Academic Council of The Academy of Municipal Engineering (Uchenyy Sovet Akademii Kommunalnogo Hozyaystva) in Kommunalnoe Stroitelstvo, 1938, No 11-12, pp.46-47 [in Russian]

[20] M.M.Izhevsky, On the Rules and Regulations of Urban Planning (O Pravilah I Normah Planirovki Gorodov) in Kommunalnoe Stroitelstvo, No 3-4, pp.4-6 [in Russian].

[21] Academy of Municipal Engineering. Regulations of Urban Planning. Project (Stroyizdat Narkomstroy, Akademiya Kommunalnogo Hozyaystva. Normy Planirovki Gorodov. Proekt. Stroyizdat Narkomstroya), 1940 [in Russian]. 